\title{
Prosta metoda selekcji materiałów hodowlanych pszenicy i pszenżyta z wykorzystaniem nieoczyszczonego filtratu zawierającego efektor Tox3
}

\section{A simple method of selecting wheat and triticale breeding materials using a crude filtrate containing the Tox3 effector}

\author{
Jakub Walczewski ${ }^{凶}$
}

\author{
Instytut Hodowli i Aklimatyzacji Roślin - Państwowy Instytut Badawczy, Radzików, 05-870 Błonie, Polska, \\ Zakład Fitopatologii, \\ $\triangle$ e-mail: j.walczewski@ihar.edu.pl
}

\begin{abstract}
Parastagonospora nodorum jest powszechnie występującym nekrotroficznym patogenem zbóż atakującym przede wszystkim pszenżyto i pszenicę, wywołuje on septoriozę liści i plew, która w sprzyjających warunkach pogodowych powoduje duże straty w plonie. Patogen ten wykorzystuje szereg specyficznych białkowych efektorów, które u wrażliwych genotypów uruchamiają szlaki sygnałowe prowadzące do programowanej śmierci komórek, w wyniku, czego powstają zmiany nekrotyczne w zainfekowanej tkance. W powyższej pracy przedstawiono procedurę testowania obiektów hodowlanych pod względem wrażliwości na efektor Tox3 z wykorzystaniem nieoczyszczanego filtratu z hodowli P. nodorum. Podejście to pozwala osiągnąć zadowalające efekty selekcji bez konieczności stosowania kłopotliwych procedur oczyszczania lub ekspresji opartej o genetycznie zmodyfikowane mikroorganizmy.
\end{abstract}

\begin{abstract}
Słowa klucze: effektory, SNB, nodorum, nekrotrof, selekcja, hodowla odpornościowa.
Parastagonospora nodorum is a wide spread necrotrophic pathogen of crop that primary attack wheat and triticale. It is casual agent of septoria nodorum leaf and glume blotch (SNB), which in favorable weather conditions causes large yield losses. This pathogen uses a number of specific protein effectors that in sensitive genotypes trigger signaling pathways leading to programmed cell death, resulting in necrotic changes in infected tissue. This work presents the procedure for testing breeding objects for sensitivity to the Tox 3 effector using non-purified filtrate from P. nodorum culture. This approach allows achieving satisfactory selection results without the need for troublesome purification procedures or expression based on genetically modified microorganisms.
\end{abstract}

Key words: effectors, SNB, nodorum, necrotroph, selection, resistance breeding.

Patogeny nekrotroficzne charakteryzują się tym, że swoją strategię rozwojową opierają na indukcji u gospodarza zmian nekrotycznych, w których znajdują środowisko do rozwoju i rozmnażania oraz z których czerpią substancje odżywcze. Do najlepiej poznanych patogenów nekrotroficznych atakujących zboża, szczególnie pszenicę i pszenżyto należy Parastagonospora nodorum (Septoria nodorum) wywołujący septoriozę liści i plew. Jest to kosmopolityczny patogen powodujący największe straty $\mathrm{w}$ rejonach świata charakteryzującym się ciepłym i wilgotnym klimatem. Patogen ten występuje powszechnie na terenie Polski. W sprzyjających warunkach porażenie przybiera epidemiczny charakter przyczyniając się do dużego obniżenia, jakości oraz ilości plonu. Klasyczny pogląd na temat dziedziczenia odporności na ten patogen zakładał udział wielu locii ilościowych w tym procesie (Francki 2013). Ostatnie badanie ujawniły wykorzystywanie przez patogen wielu białkowych efektorów, które po rozpoznaniu przez specyficzne dla danego efektora receptory prowadzą do indukcji programowanej śmierci komórki w zaatakowanej tkance. Odporność na poszczególne efektory jest dziedziczona recesywnie. Dotychczas opisano 8 osobnych oddziaływań efektor-receptor (Friesen i inni 2006, 2007; Liu i inni 2006, 2009; Abeysekara i inni 2009; Gao i inni 2015; Shi i inni 2015). Oddziaływania te mają głównie charakter addytywny (Friesen i inni 2010). Pula genowa pszenicy i pszenżyta, warunkuje zróżnicowaną odporność tych zbóż na poszczególne efektory. Podobnie populacja patogenu jest zróżnicowana pod względem zdolności do produkcji efektorów oraz poziomu ich ekspresji (McDonald i inni 2013, Faris i inni 2011). 
Wykorzystanie w hodowli odpornościowej selekcji opartej o metody wynikające bezpośrednio $\mathrm{z}$ molekularnych mechanizmów patogenezy, pozwala uniezależnić ten proces od kłopotliwych i nie zawsze powtarzalnych badań fenotypowych, a w rezultacie skrócić i ułatwić ten proces. Wymaga to jednak dostępu do dużych ilości preparatów zawierających efektory, których pozyskanie może być kłopotliwe, gdyż w praktyce wiąże się z wykorzystaniem do procesu produkcji genetycznie modyfikowanych mikroorganizmów, lub mozolnym oczyszczaniem efektorów z użyciem metod chromatograficznych.

Celem tej pracy jest wskazanie ogólnodostępnego izolatu $P$. nodorum wraz z metodyką pozyskania jego ekwiwalentu oraz prostej dostępnej dla niewyspecjalizowanych laboratoriów procedury wytworzenia $\mathrm{z}$ jego pomocą preparatu umożliwiającego testowanie materiałów roślinnych pod względem wrażliwości na efektor Tox3.

\section{Materiały i Metody:}

Pożywka płynna Frie: $5 \mathrm{~g}$ winianu amonu, $1 \mathrm{~g}$ azotan amonu, 0,5g siarczan magnezu $\left(7 \mathrm{H}_{2} \mathrm{O}\right), 1,3 \mathrm{~g}$ fosforan potasu jednozasadowy, $2,6 \mathrm{~g}$ fosforan potasu dwuzasadowy, 30g sacharoza, $1 \mathrm{~g}$ ekstrakt drożdżowy na $1000 \mathrm{ml}_{2} \mathrm{O}$. Autoklawowanie 20min $120^{\circ} \mathrm{C}$. Fosforan potasu dwuzasadowy autoklawowany osobno i dodawany po ostygnięciu.

Pożywka YPD (Yeast extract Peptone Dextrose): $10 \mathrm{~g}$ ekstrakt drożdżowy, 20g pepton, $20 \mathrm{~g}$ glukoza (filtrowana dodawana po ostygnięciu) na $1000 \mathrm{ml} \mathrm{H}_{2} \mathrm{O}$. Autoklawowanie $20 \mathrm{~min} \mathrm{w} 120^{\circ} \mathrm{C}$.

Pożywka zbożowa stała: $34 \mathrm{~g}$ ziarniaków pszenżyta w $1000 \mathrm{ml}$ wody demineralizowanej, zaparzane w $95^{\circ} \mathrm{C}$ przez 20 min. Po odsączeniu dodawane $30 \mathrm{~g}$ agaru. Autoklawowanie $20 \mathrm{~min} \mathrm{w} 120^{\circ} \mathrm{C}$.

Agar do izolacji: $45 \mathrm{~g}$ agaru na $1000 \mathrm{ml} \mathrm{H}_{2} \mathrm{O}$. Autoklawowanie $20 \mathrm{~min} \mathrm{w} 120^{\circ} \mathrm{C}$.

Izolacja DNA: Odsączona grzybnia pochodząca $\mathrm{z}$ hodowli płynnej na pożywce Frie, była dwukrotnie przemywana sterylną wodą, następnie rozcierana w ciekłym azocie przy pomocy moździerza. 20mg utartej grzybni wykorzystano do izolacji DNA według González-Mendoza i inni [2010].

Analiza PCR efektorów:

Startery:

ToxAF CGTCCGGCTACCTAGCAATA,

ToxAR TTGTGCTCCTCCTTCTCGA,

Tox3F CTCGAACCACGTGGACCCGGA,

Tox3R CTCCCCTCGTGGGATTGCCCCATATG,

Tox1F ATGAAGCTTACTATGGTCTTGT, Tox1R TGTGGCAGCTAACTAGCACA.
Skład $10 \mu 1$ mieszaniny reakcyjnej: $1 \mu 1-50 \mathrm{ng} /$ $\mu \mathrm{l}$ matrycy, $1 \mu \mathrm{l}-5 \mathrm{mM}$ mieszaniny starterów, $0,2 \mu 1$ - $10 \mathrm{mM}$ mieszaniny dNTP, $0,05 \mu 1$ - DreamTaq DNA Polymerase, $1 \mu 1$ - DreamTaq Green Buffer, $6,75 \mu 1-\mathrm{H}_{2} \mathrm{O}$. Program PCR. Wstępna denaturacja: $95^{\circ} \mathrm{C} 5$ min. 35 cykli: $95^{\circ} \mathrm{C} 45 \mathrm{~s}$ denaturacja, $63^{\circ} \mathrm{C}$ 45 s przyłączanie, $72{ }^{\circ} \mathrm{C} 1 \mathrm{~min}$ elongacja. Końcowa elongacja $72^{\circ} \mathrm{C} 10 \mathrm{~min}$.

Kultura stała Parastagonospora nodorum: Zaszczepione szalki inkubowano $\mathrm{w} 20^{\circ} \mathrm{C}, 12 \mathrm{~h}$ fotoperiod. Źródło światła: świetlówki Exo Terra Repti Glo 10.0.

Produkcja filtratu Tox3 w Parastagonospora nodorum: Kolbki wypełnione w $20 \%$ pożywką Frie, szczepiono fragmentem agaru $\mathrm{z}$ widocznymi pyknidiami. Hodowla na wytrząsarce: 200rpm, $27^{\circ} \mathrm{C}$, w ciemności, przez $72 \mathrm{~h}$. Następnie przez 28 dni w ciemności bez wytrząsania w temperaturze pokojowej. Kulturę płynną filtrowano przez bibułę filtracyjną a następnie przez filtr $0,45 \mu \mathrm{m}$ i wykorzystano do infiltracji roślin. Do produkcji efektora Tox3 wykorzystano izolat Sn13-1-1 dostępny w kolekcji roboczej Zakładu Fitopatologii.

Izolacja P.nodorum ze środowiska: Suchy liść z widocznymi pyknidiami, umieszczono w sterylnej szalce na bibułce namoczonej sterylną $\mathrm{H}_{2} \mathrm{O}$. Po wypłynięciu masy zarodnikowej rozmazano ją przy pomocy sterylnej igły na szalce $\mathrm{z}$ agarem do izolacji. Następnie przeniesiono pojedynczy zarodnik przy pomocy mikromanipulatora na pożywkę zbożową, bądź inkubowano szalkę w $20^{\circ} \mathrm{C}$ w ciemności do chwili, gdy była widoczna rozwijająca się grzybnia, którą przeniesiono na pożywkę zbożową.

Produkcja Tox3: Szczep Pichia pastoris zawierający plazmid pGAPZA ze sklonowanym genem Tox3, zaszczepiono na pożywkę płynną YPD. Hodowano 3 dni, wytrząsanie 200rpm, temperatura $30^{\circ} \mathrm{C}$. Kulturę zwirowano oraz przefiltrowano przez filtr o średnicy porów $0,44 \mu \mathrm{m}$. Preparat zawierający Tox3 wykorzystano do infiltracji roślin.

Oczyszczanie Tox5: Filtrat $\mathrm{z}$ hodowli izolatu 76-40 pochodzącego z kolekcji roboczej Zakładu Fitopatologii, poddano 2 krotnej dializie w 10 objętościach roztworu zawierającego $20 \mathrm{mM}$ octanu sodu i $20 \mathrm{mM} \mathrm{NaCl}$ o $\mathrm{pH} 5$, z wykorzystaniem membrany zatrzymującej cząsteczki o wymiarach 6-8 kDa. Dializat naniesiono na kolumnę chromatograficzną zawierającą złożę SP-Sepharose i wymywano gradientem $\mathrm{NaCl}$ od 0 do $200 \mathrm{mM}$. Frakcje zawierające Tox 5 określono poprzez infiltrację wrażliwego obiektu LP749-29, oraz zagęszczono poprzez ultrafiltrację i wykonano sączenie żelowe z wykorzystaniem złoża Superdex 75 w $20 \mathrm{mM}$ octanu 
sodu 100mM NaCl pH 6. Przy pomocy wrażliwego obiektu określono frakcje aktywne, które wykorzystywano w badaniach.

Infiltracja roślin: Przy pomocy strzykawki $1 \mathrm{ml}$ przyłożonej delikatnie do górnej powierzchni w pełni rozwiniętego drugiego liścia siewki, powoli wtłaczano przez aparaty szparkowe filtrat. Pisakiem zaznaczono obszar infiltracji. Po ok 5 dniach wykonano ocenę, uznając za podatne obiekty, które w zaznaczonym obszarze wykazują całkowitą nekrozę (rys. $1 \mathrm{C}$ ), bądź lżejsze zmiany o charakterze zaawansowanej chlorozy (rys.1 B). Obiekty niewrażliwe nie wykazują żadnych zmian w granicach infiltrowanego obszaru (rys.1 A). W przypad$\mathrm{ku}$, gdy filtrat ma zbyt niskie $\mathrm{pH}$, w bezpośrednim sąsiedztwie miejsca przyłożenia strzykawki pojawia się charakterystyczna nekroza, nieobejmująca swoim zasięgiem całego infiltrowanego rejonu (rys.1 D). Dla każdego obiektu roślinnego doświadczenie było prowadzone w 3 powtórzeniach, gdzie jedno powtórzenie stanowiła siewka.

Material roślinny: $\mathrm{Na}$ podstawie wstępnych badań wybrano łatwo dostępne na Polskim rynku odmiany pszenicy: Operetka, Natula, Torrild, oraz pszenżyta: Borowik i Cyrkon. Odmiany te umożliwiają analizę izolatów $P$. nodorum pod kątem produkcji efektorów Tox3 i Tox5. W badaniach w celach porównawczych wykorzystano również obiekty pszenicy BG220 i LP749-29 będące opisanymi w literaturze liniami różnicującymi dla efektorów Tox3 i Tox5.
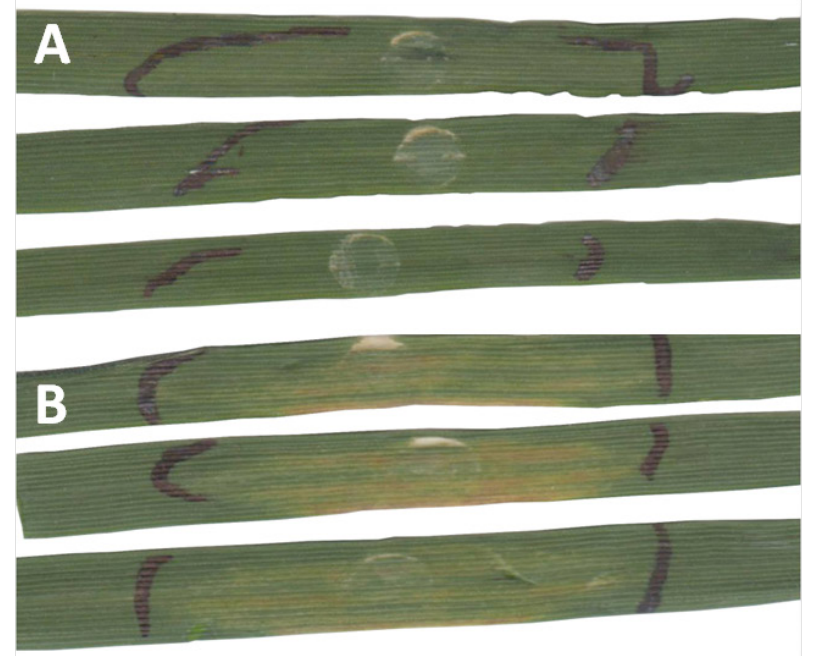

\section{Wyniki}

We wstępnych badaniach izolat Sn13-1-1 wykorzystywano, jako źródło filtratu do złożonego z kilku etapów chromatograficznego procesu oczyszczania efektora Tox3.

W celu określenia, jakie efektory są potencjalnie produkowane przez izolat Sn13-1-1 z grzybni pozostałej po odsączeniu filtratu wyizolowano DNA, które wykorzystano do przeprowadzenia reakcji PCR ze starterami dla genów kodujących efektory Tox1, Tox3 i ToxA. Po analizie elektroforetycznej określono, że izolat Sn13-1-1 zawiera gen Tox3 natomiast nie zawiera genów Toxl i ToxA (tab. 1).

W celu sprawdzenia czy poza Tox3 izolat Sn13-1-1 produkuje również efektor Tox 5 przez 28 dni prowadzono kulturę płynną, którą następnie odfiltrowano i wykorzystano do infiltracji liści łatwo dostępnych w Polsce odmian różnicujących oba efektory. Zestaw ten infiltrowano również przy pomocy wypreparowanych efektorów Tox3 i Tox5. W wyniku infiltracji wykazano, że odmiany

\section{Tabela 1}

Table 1.

Efektory produkowane przez izolat 13-1-1.

Effectors produced by isolate 13-1-1.

\begin{tabular}{|c|c|c|c|c|}
\hline $\begin{array}{l}\text { Izolat } \\
\text { Izolate }\end{array}$ & $\begin{array}{l}\text { Produkcj } \\
\text { Producti }\end{array}$ & $\begin{array}{l}\text { rów } \\
\text { fectors }\end{array}$ & & \\
\hline \multirow{2}{*}{$13-1-1$} & Tox1 & Tox3 & Tox 5 & ToxA \\
\hline & - & + & - & - \\
\hline
\end{tabular}
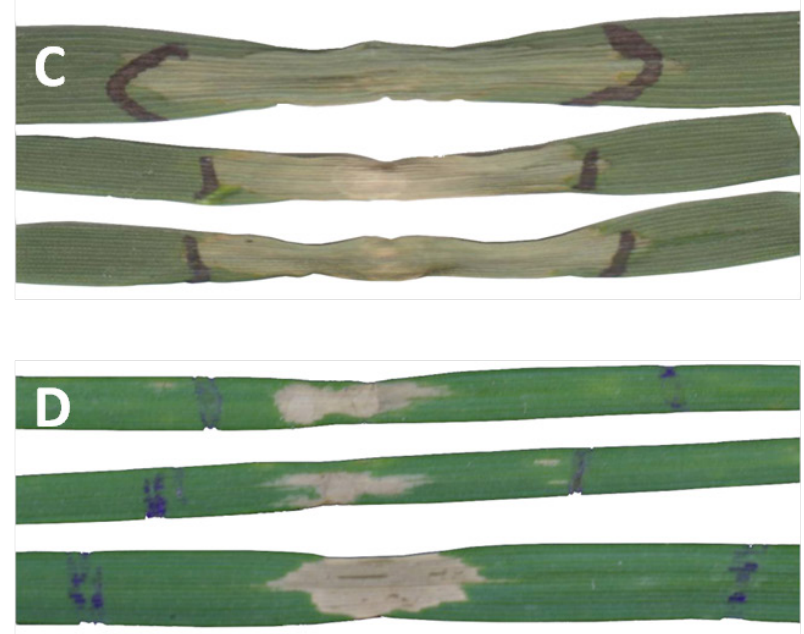

Rys. 1. Rodzaje reakcji infiltrowanych liści na efektor Tox3: (A) niewrażliwe, (B) reakcja pośrednia, (C) wrażliwe, (D) miejsce infiltracji uszkodzone przez niskie $\mathbf{p H}$.

Fig. 1. Reaction types of leaves infiltrated with Tox3 effector: (A) insensitive, (B) intermediate, (C) sensitive, (D) infiltration place damaged by low $\mathrm{pH}$. 
pszenicy Operetka i Natula oraz pszenżyto Borowik są wrażliwe zarówno na efektor Tox3 pochodzący z systemu ekspresyjnego jak i na nieoczyszczony filtrat izolatu Sn13-1-1, a niewrażliwe na oczyszczony preparat Tox5. Odmiana pszenicy Torrild oraz pszenżyta Cyrkon są wrażliwe na Tox5 a niewrażliwe na oba preparaty Tox3. Obiekty pszenicy jarej BG220 oraz LP749-29 są obiektami wykorzystywanymi w literaturze do różnicowania efektorów Tox3 oraz Tox5, ich reakcja na oczyszczone efektory oraz filtrat Sn13-1-1 potwierdziły, że zawiera on efektor Tox3 a nie zawiera Tox5 (tab. 2).

\section{Dyskusja}

Niewrażliwość na efektory białkowe ma wpływ na wykazywaną odporność na $P$. nodorum w warunkach polowych (Ruud i inni 2017). Trzy z nich Tox1, Tox3 oraz ToxA zostały sklonowane i są produkowane w systemach ekspresyjnych na masową skalę, oraz wykorzystywane do selekcji w programach hodowlanych pszenicy (Tan i inni 2014). Wykorzystanie systemów ekspresyjnych opartych o genetycznie zmodyfikowane mikroorganizmy, wiąże się z potrzebą posiadania odpowiednio wyposażonego laboratorium, spełnienia wymogów formalnych

Tabela 1

Table 1.

Odmiany różnicujące wrażliwość na najpopularniejsze efektory.

Differential cultivars for most common effectors.

\begin{tabular}{|c|c|c|c|}
\hline \multirow[b]{2}{*}{$\begin{array}{l}\text { Odmiana } \\
\text { Cultivar }\end{array}$} & \multicolumn{3}{|c|}{$\begin{array}{l}\text { Wrażliwość na ekstrakt } \\
\text { Extract sensitivity }\end{array}$} \\
\hline & $\begin{array}{l}\text { Surowy filtrat } \\
13-1-1 \\
\text { Crude filtrate } \\
13-1-1\end{array}$ & $\begin{array}{l}\text { Oczyszczony } \\
\text { Tox3 } \\
\text { Purified Tox3 }\end{array}$ & $\begin{array}{l}\text { Oczyszczony } \\
\text { Tox } 5 \\
\text { Purified Tox } 5\end{array}$ \\
\hline BG 220 & $\begin{array}{l}\text { Wrażliwa } \\
\text { Sensitive }\end{array}$ & $\begin{array}{l}\text { Wrażliwa } \\
\text { Sensitive }\end{array}$ & $\begin{array}{l}\text { Niewrażliwa } \\
\text { Insensitive }\end{array}$ \\
\hline LP749-29 & $\begin{array}{l}\text { Niewrażliwa } \\
\text { Insensitive }\end{array}$ & $\begin{array}{l}\text { Niewrażliwa } \\
\text { Insensitive }\end{array}$ & $\begin{array}{l}\text { Wrażliwa } \\
\text { Sensitive }\end{array}$ \\
\hline Cyrkon & $\begin{array}{l}\text { Niewrażliwa } \\
\text { Insensitive }\end{array}$ & $\begin{array}{l}\text { Niewrażliwa } \\
\text { Insensitive }\end{array}$ & $\begin{array}{l}\text { Wrażliwa } \\
\text { Sensitive }\end{array}$ \\
\hline Borowik & $\begin{array}{l}\text { Wrażliwa } \\
\text { Sensitive }\end{array}$ & $\begin{array}{l}\text { Wrażliwa } \\
\text { Sensitive }\end{array}$ & $\begin{array}{l}\text { Niewrażliwa } \\
\text { Insensitive }\end{array}$ \\
\hline Torrild & $\begin{array}{l}\text { Niewrażliwa } \\
\text { Insensitive }\end{array}$ & $\begin{array}{l}\text { Niewrażliwa } \\
\text { Insensitive }\end{array}$ & $\begin{array}{l}\text { Wrażliwa } \\
\text { Sensitive }\end{array}$ \\
\hline Natula & $\begin{array}{l}\text { Wrażliwa } \\
\text { Sensitive }\end{array}$ & $\begin{array}{l}\text { Wrażliwa } \\
\text { Sensitive }\end{array}$ & $\begin{array}{l}\text { Niewrażliwa } \\
\text { Insensitive }\end{array}$ \\
\hline
\end{tabular}

związanych ze statusem prawnym GMM (Genetycznie Modyfikowanych Mikroorganizmów), oraz warunków licencyjnych, którymi podlegają komercyjnie dostępne systemy ekspresyjne. Również oczyszczanie efektorów do postaci homogenicznych białek metodami chromatograficznymi jest procesem kosztownym i skomplikowanym. Powoduje to, że początkowe nakłady wprowadzenia selekcji materiałów roślinnych z wykorzystaniem efektorów do programów hodowlanych są wysokie a proces jest kłopotliwy.

Rozwiązaniem zmniejszającym próg wejścia, może być uproszczenie procesu poprzez wykorzystanie częściowo oczyszczonych filtratów z hodowli wyselekcjonowanych izolatów $P$. nodorum produkujących tylko wybrane efektory. Przedstawiony w powyższej pracy izolat Sn13-1-1 może być z powodzeniem wykorzystany do prostej produkcji filtratu zawierającego Tox3. Jego przydatność do tego celu potwierdziło wykluczenie poprzez badania PCR oraz powtarzane testy biologiczne, produkcji innych efektorów. Powodowane przez niego zmiany nekrotyczne u wrażliwych obiektów niczym nie różniły się od zmian powodowanych przez preparaty Tox3 pochodzące $\mathrm{z}$ transgenicznych systemów ekspresyjnych.

Reakcja obiektów pszenicy i pszenżyta na preparat zawierający efektor Tox3 jest powtarzalna. Pojawianie się zmian nekrotycznych można zaobserwować już po 48h, a infiltracja nawet kilku liści jednej siewki nie powoduje niebezpieczeństwa jej utracenia. Z tego powodu badania wrażliwości na efektor Tox 3 mogą być prowadzone równolegle z innymi czynnościami hodowlany na tym samym materiale, co dodatkowo może ograniczyć koszty wprowadzenia tej metody do programów hodowlanych.

\section{Wnioski}

1. Wykorzystanie $\mathrm{w}$ hodowli odpornościowej na $P$. nodorum, selekcji materiałów z wykorzystaniem białkowych efektorów, może uniezależnić ten proces od nie zawsze powtarzalnych i kłopotliwych badań fenotypowych.

2. Wykorzystanie do produkcji efektorów odpowiednich izolatów $P$. nodorum może obniżyć koszty i ułatwić wprowadzenie tej metody do programów hodowlanych.

3. Izolat $P$. nodorum Sn13-1-1 może być wykorzystany, jako tanie źródło efektora Tox3

4. Opisana metodyka oraz zestaw odmian może być wykorzystana do selekcji izolatów o podobnych właściwościach. 


\section{Literatura}

Abeysekara N., Friesen T. L., Keller B., Faris J. (2009) Identification and characterization of a novel host-toxin interaction in the wheat-Stagonospora nodorum pathosystem. Theoret Appl Genetics 120:117-126

Faris J. D., Zhang Z. Rasmussen J. B., Friesen T. L. (2011) Variable expression of the Stagonospora nodorum effector SnToxA among isolates is correlated with levels of disease in wheat. Mol. Plant Microbe Interact. 24: 14191426.

Francki M. G. (2013) Improving Stagonospora nodorum resistance in wheat: a review. Crop Sci 53:355-365

Friesen T. L., Stukenbrock E. H., Liu Z., Meinhardt S., Ling H., Faris J. D., Rasmussen J. B., Solomon P. S., McDonald B. A., Oliver R. P. (2006) Emergence of a new disease as a result of interspecific virulence gene transfer. Nat Genet 38:953-956

Friesen T. L., Meinhardt S. W., Faris J. D. (2007) The Stagonospora nodorum-wheat pathosystem involves multiple proteinaceous host-selective toxins and corresponding host sensitivity genes that interact in an inverse gene-forgene manner. Plant J. Cell Mol Biol 51:681-692

Friesen T. L., Faris J. D. (2010) Characterization of the wheat -Stagonospora nodorum disease system: what is the molecular basis of this quantitative necrotrophic disease interaction? Can J. Plant Pathol-Rev Can Phytopathol 32:20-28

Gao Y., Faris J. D., Liu Z., Kim Y. M., Syme R. A., Oliver R. P., Xu S. S., Friesen T. L. (2015) Identification and characterization of the SnTox6-Snn6 interaction in the Parastagonospora nodorum-wheat pathosystem. Mol Plant Microbe Interact M. P.I 28:615-625
González-Mendoza D., Argumedo-Delira R., Morales-Trejo A., Pulido-Herrera A., Cervantes-Díaz L., Grimaldo-Juarez O., Alarcón A. (2010) A rapid method for isolation of total D. N. from pathogenic filamentous plant fungi. Genet. Mol. Res. 9 (1): 162-166 (2010)

Liu Z., Friesen T. L., Ling H., Meinhardt S. W., Oliver R. P., Rasmussen J. B., Faris J. D. (2006) The Tsn1-ToxA interaction in the wheat-Stagonospora nodorum pathosystem parallels that of the wheat-tan spot system. Genome 49:1265-1273

Liu Z., Faris J. D., Oliver R. P., Tan K. C., Solomon P. S., McDonald M. C., McDonald B. A., Nunez A., Lu S., Rasmussen J. B., Friesen T. L. (2009) SnTox3 acts in effector triggered susceptibility to induce disease on wheat carrying the Snn3 gene. P. L.S Pathog 5:e1000581

McDonald M. C., Oliver R. P., Friesen T. L., Brunner P. C. and McDonald B. A. (2013), Global diversity and distribution of three necrotrophic effectors in Phaeosphaeria nodorum and related species. New Phytol, 199: 241-251

Ruud A. K., Windju S., Belova T., Friesen T. L., Lillemo, M. (2017) Mapping of SnTox3-Snn3 as a major determinant of field susceptibility to Septoria nodorum leaf blotch in the S. H.3/C.B.D $\times$ Naxos population. TheorApplGenet 130: 1361

Shi G., Friesen T. L., Saini J., Xu S. S., Rasmussen J. B., Faris J. D. (2015) The wheat gene confers susceptibility on recognition of the necrotrophic effector SnTox7. Plant Genome 8:1-10

Tan K. C., Waters O. D., Rybak K., Antoni E., Furuki E., Oliver R. P. (2014) Sensitivity to three Parastagonospora nodorum necrotrophic effectors in current Australian wheat cultivars and the presence of further fungal effectors. Crop Pasture Sci 65:150-158

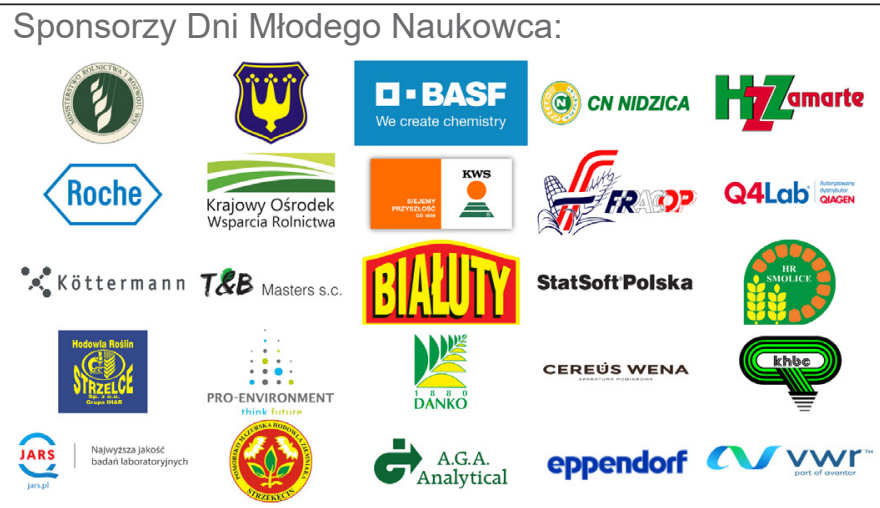

